\title{
A Real Time Approach to Theft Prevention in the field of Transportation System
}

\author{
Vartika Mehta ${ }^{1}$, Deepak Punetha ${ }^{2}$, Vishwanath Bijalwan ${ }^{3}$ \\ ${ }^{1}$ Department of Electronics \& Communication Engineering, SIT, Pithoragarh \\ ${ }^{2}$ Department of Electronics \& Communication Engineering, Tula's Institute, Dehradun \\ ${ }^{3}$ Department of Electronics \& Communication Engineering, IT, Gopeshwar
}

\begin{abstract}
This paper report discusses a theft prevention system, which can prevent the theft and also can be track the object. This system is capable to tracking the vehicle as well as theft prevention. An R.F. module is use to exchange the information regarding vehicle and owner of the vehicle with police control room or SOS services. The vehicle can be track with the help of R.F. receiver. A DTMF based fuel lock has been attached in this system. A cell phone with SIM card has been attached with DTMF IC. The fuel flow in the vehicle can be controlled by give a call to this cell phone. This system has been controlled by a microcontroller which can make the system cost effective, low power consumption, effective and reliable.
\end{abstract}

Keywords - Theft Preventation, Tracking, RF module, DTMF, Microcontroller, Mobile Phone.

\section{INTRODUCTION}

$\mathrm{V}_{\mathrm{p}}$ EHICLE Prevention system is primary concern for everyone to prevent robberies of vehicle. Research shows that there are thousands of vehicles have stolen every year. These crimes are increasing day by day. In this paper report a system has been developed by use of RFID and DTMF. This process is called Dual Tone Multiple Frequency based Vehicle Prevention System using RFID.

There are two type of prevention system exist "Active system and Passive system". Active System transfers all information about the vehicle to police control room via cellular. Passive devices are used for knowing about the location and it is also used as trigger for ON/OFF the fuel or door of the vehicle.

Vehicle Prevention System is the solution to overcome this problem. By using RFID people can know about the location of the vehicle and with the help of Dual Tone Multiple Frequency people can lock the fuel of vehicle.

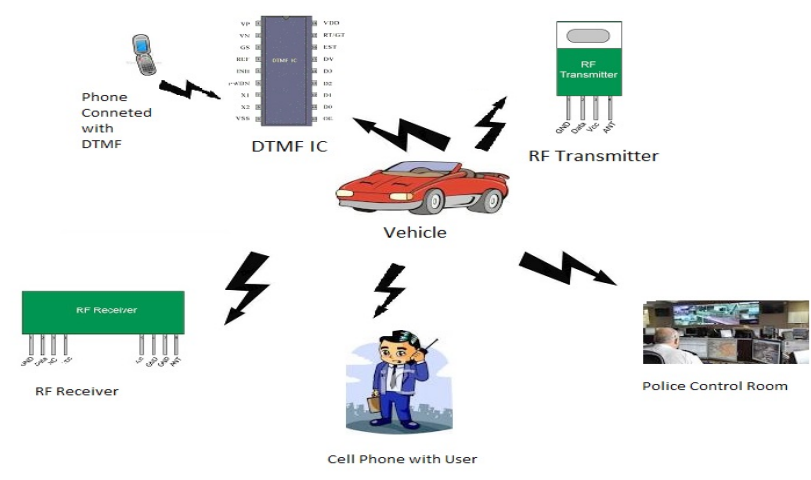

Fig. 1. Vehicle Tracking System Procedure
Vehicle Prevention System is a system which provides the effective, reliable and real time vehicle location. So many organization and researcher are working in the field of transportation system [1-3].

\section{Motivation}

Around the world thousands of vehicles theft occur because of low security. If the people go somewhere in its vehicle due to some work then they want to their vehicle should be safe. For every problem RTO is making the case study. Research shows that above from thousands vehicle has been stolen in one state. Because of Lake of awareness the crime is increasing day by day. Report of government shows the robberies occurs in Haryana state. Following table is showing the detail of vehicle which has been stolen.

TABLE 1. TABLE OF STOLEN VEHICLE AND ITS DETAIL

\begin{tabular}{|c|c|c|c|c|c|}
\hline $\begin{array}{c}\text { S. } \\
\text { No. }\end{array}$ & $\begin{array}{c}\text { Type of } \\
\text { vehicle }\end{array}$ & Make & Regd. Num & $\begin{array}{c}\text { Place of } \\
\text { occurrence }\end{array}$ & $\begin{array}{c}\text { Date of } \\
\text { occurrence }\end{array}$ \\
\hline 1 & M/CYCLE & SPL & HR07M-4915 & $\begin{array}{c}\text { COMMERCIAL } \\
\text { AREA }\end{array}$ & $04-05-15$ \\
\hline 2 & M/CYCLE & SPL+ & HR02U-7402 & $\begin{array}{c}\text { COMMERCIAL } \\
\text { AREA }\end{array}$ & $14-05-15$ \\
\hline 3 & CAR & $\begin{array}{c}\text { MARUTI } \\
\text { DESIRE }\end{array}$ & D13A1604344 & $\begin{array}{c}\text { COMMERCIAL } \\
\text { AREA }\end{array}$ & $25-05-15$ \\
\hline 4 & CANTER & TATA 407 & HR46A-4057 & $\begin{array}{c}\text { COMMERCIAL } \\
\text { AREA }\end{array}$ & $26-05-15$ \\
\hline 5 & TRACTOR & MAHINDRA & RAR5603 & $\begin{array}{c}\text { COMMERCIAL } \\
\text { AREA }\end{array}$ & $26-05-15$ \\
\hline 6 & JEEP & PICK UP & M28984 & $\begin{array}{c}\text { COMMERCIAL } \\
\text { AREA }\end{array}$ & $26-05-15$ \\
\hline
\end{tabular}

\section{Problem Definition}

The strategy of solving these problems is use the tracking system the vehicle. This tracking system should inbuilt in the vehicle. Stolen vehicle can be track easily by its area of police station. According to govt. report robberies is increasing very fast. Further reducing these issues government will take the step to use this system.

\section{RELATED WORK}

Montaser N. Ramadan et. al describe the anti-theft system, which can detect the location of vehicle by using GPS module. It gives approximately 10 meter difference to detect object from exact location. Detecting location using GPS is also very costly [3]. K. P. Kamble elaborate the system which can save petrol, gas, time and also optimize the driver route and can control the function of vehicle. The accuracy 
of this system is not good [4]. D. Narendar Singh et.al illustrate real time vehicle theft identity for recognize the face of driver of vehicle by using PCA. With the help of face detection people can detect the face of thief but in case of wearing mask PCA can't detect the face [5]. Some system describes the study of auto theft prevention in which system makes use of microcontroller and it is connected to interfacing GSM for controlling the theft of vehicle. GSM work on AT command, sometime GSM can't read these commands and can't work properly [6-9]. A methodology defined the Vehicle Accident Alert and Locator which can detect the vehicle when it meet with accident. This system is reliable for people. It can detect vehicle when there will be a little vibration in vehicle [10]. Some systems present concise overview of detecting and tracking of vehicle. This system plays a vital role in civilian and military environment such as in management and urban traffic planning, highway traffic surveillance control by video. In this system protection of camera is very important [11-14]. Many systems have been proposed which can detect the crash detection and a lot of work done in the field of transportation system.

\section{System Overview}

This system can give the great contribution in the field of vehicle tracking in army, navy and somewhere in police department. This system contains the RF module, DTMF, cell phone and controlled device [16-18].

\section{A. RF module}

The RF transmitter is able to transmit the radio frequency containing the information about the vehicle.

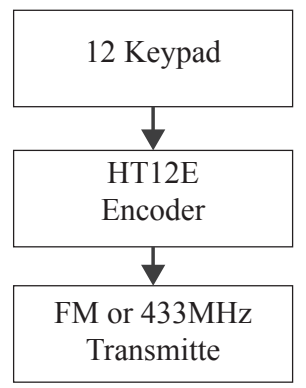

Fig. 2. Block diagram of RF transmitter

HT12E encoder and HT12D decoder is used by RF transmitter and $\mathrm{RF}$ receiver respectively. Operating voltage of these encoder and decoder is $2.4 \mathrm{~V}$ to $12 \mathrm{~V}$.

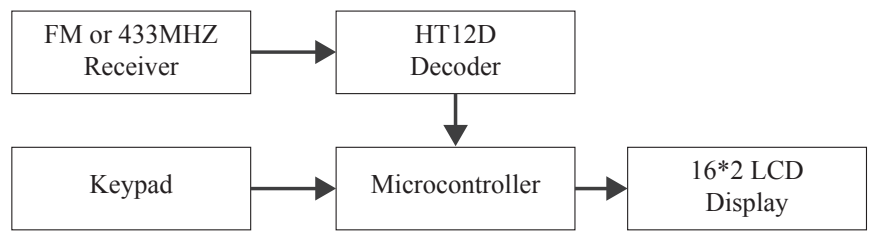

Fig. 3. Block diagram of RF receiver

\section{B. DTMF}

DTMF stand for Dual Tone Multiple Frequency. Moving object can be control by using mobile phones. This system requires two phones. Amongst them one with SIM card connected with RF transmitter and another phone will keep the vehicle owner. Phone connected with RF transmitter is put in such a mode that it automatically picks up the call. When the owner will call on that number, the call can activate automatically and owner can lock the fuel with help of DTMF. Solenoid can use for locking the fuel.

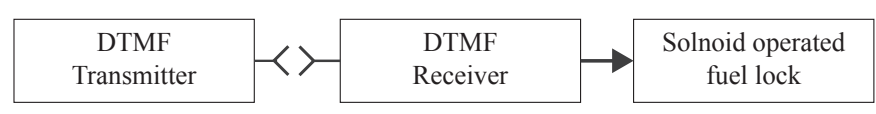

Fig. 4. DTMF Transmitter and DTMF based fuel lock.

\section{System Setup}

This system is defined as the tracking of moving object. The proposed system contains RFID which has a specific range. It can be categorized in different sections such as RF transmitter, RF receiver and DTMF fuel lock. RF transmitter can attach with the vehicle. Transmitter uses the HT12E encoder and transmits the 12 bit code. This encoder is the series of CMOS LSIs and also capable for encoding data. These data have $\mathrm{N}$ numbers of address bit and 12 data bit. The programmed address/data are conveyed together. Its operating voltage is $2.4 \mathrm{~V}$ to $12 \mathrm{~V}$. The second section in this system is RF receiver. HD12D uses in the receiver section. It is a series of CMOS LSI and receives serial address and data and compares it continuously with local address. If there are any unmatched code then the input data code are decoded and transfer it to output pin. DTMF based fuel lock is the third section of this system which installed in vehicle which can be activated and deactivated by mobile. It encoded the hybrid frequency DTMF code, IC 8870 decode it and transform it into BCD code [15].

TABLE 2. ENCODED OUTPUT

\begin{tabular}{|c|c|c|c|c|c|c|c|c|c|c|c|c|}
\hline $\begin{array}{c}\text { Pressed Mobile } \\
\text { key }\end{array}$ & 1 & 2 & 3 & 4 & 5 & 6 & 7 & 8 & 9 & $*$ & 0 & $\#$ \\
\hline D3 & 0 & 0 & 0 & 0 & 0 & 0 & 0 & 1 & 1 & 1 & 1 & 1 \\
\hline D2 & 0 & 0 & 0 & 1 & 1 & 1 & 1 & 0 & 0 & 0 & 0 & 1 \\
\hline D1 & 0 & 1 & 1 & 0 & 0 & 1 & 1 & 0 & 0 & 1 & 1 & 0 \\
\hline D0 & 1 & 0 & 1 & 0 & 1 & 0 & 1 & 0 & 1 & 1 & 0 & 0 \\
\hline
\end{tabular}

\section{EXPERIMENT RESULTS}

For explaining this project first of all sees the hardware part. There is a power supply which consist of two pin connector, four diode that is also called bridge rectifier, one ON OFF switch, capacitor is of $1000 \mu \mathrm{F}$, voltage regulator is of $5 \mathrm{~V}$ and $12 \mathrm{~V}$ and LED is also be there. Next is basic circuit of microcontroller which consists of 89S52 microcontroller, a reset circuit and a crystal oscillator. Reset circuit consists of $10 \mu \mathrm{F}$ capacitor and $10 \mathrm{~K} \Omega$ register. Crystal oscillator provides a clock frequency to microcontroller. After seeing the Fig. there is a GSM modem which is connected to microcontroller through serial port.

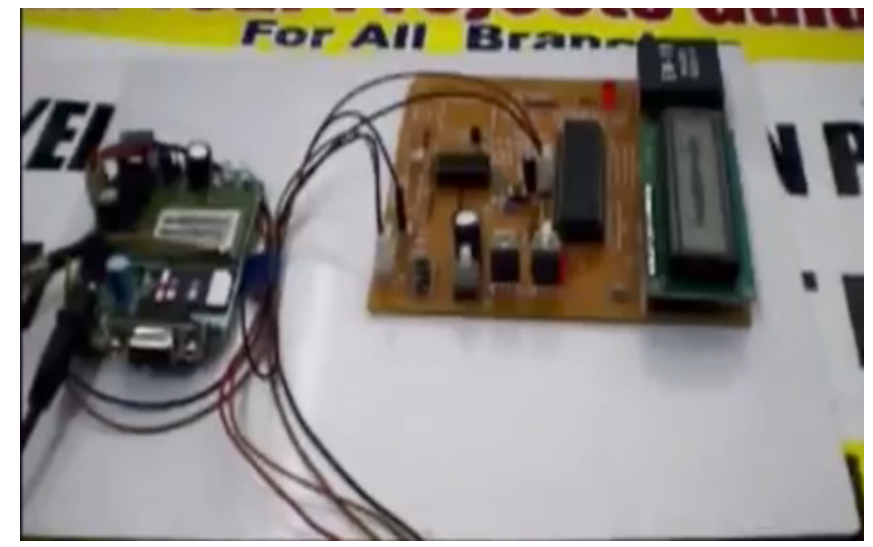

Fig. 5. Snapshot of the device 
First of all connect power supply to the circuit for initializing the modem. After connecting the power supply it takes some moment for initialization and sends an acknowledgement on the mobile. Mobile receives a message which is "Welcome to Vehicle Tracking System"

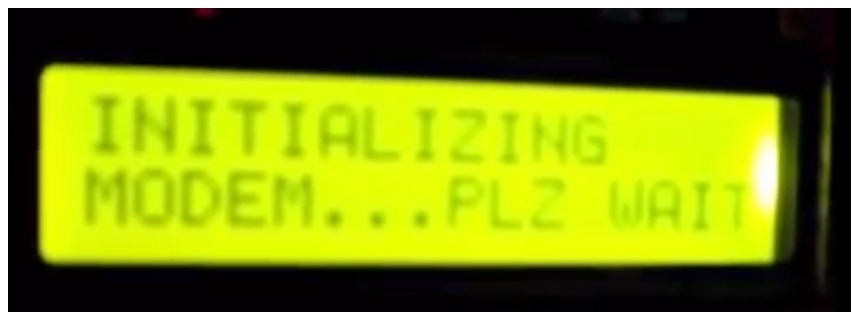

Fig. 6. Modem Initialization

If the vehicle passed through the RFID reader then LCD displays the position of vehicle and simultaneously a message sends to the mobile. This message displays on the mobile that "A vehicle name XY-0000 has been stolen and this is in your area". At another place if the vehicle is tracked then another message sends on the mobile.

\section{CONCLUSION}

Tracking system is becoming important in countries. This system is integrated in vehicle. This system is very fast, accurate and robust. It is very securing then other system. Once it will integrate in the vehicle then tracking can be very easy. After stolen the vehicle this system is capable to find the area of the vehicle where it has located with the help of RFID. Receiver part is placed in police station of every area. After tracking the vehicle first it lock the fuel by DTMF then find out the vehicle. With the help of this system vehicle can be tracked very easily.

\section{REFERENCES}

[1] Cueva-Fernandez, Guillermo, Jordán Pascual Espada, Vicente GarcíaDíaz, Rubén González Crespo, and Nestor Garcia-Fernandez, "Fuzzy system to adapt web voice interfaces dynamically in a vehicle sensor tracking application definition," Soft Computing : 1-14, 2015.

[2] García, Carlos Martín, and Gonzalo Martín Ortega, "Route planning algorithms: Planific@ project,” IJIMAI 1, no. 2 (2009): 57-66.

[3] Gechter, Franck, Bruno Ronzani, and Fabien Rioli, "Sphericall: A Human/ Artificial Intelligence interaction experience," IJIMAI 3, no. 1 (2014): 4958.

[4] Montaser N. Ramadan, Mohammad A. Al-Khedher and Sharaf A. AlKheder, "Intelligent Anti-Theft and Tracking System for Automobiles," International Journal of Machine Learning and Computing, Vol. 2, No. 1, February 2012.

[5] K.P.Kamble,"SMART VEHICLE TRACKING SYSTEM," International Journal of Distributed and Parallel Systems (IJDPS) Vol.3, No.4, July 2012.

[6] D.Narendar Singh, K.Tejaswi, "Real Time Vehicle Theft Identity and Control System Based on ARM 9," International Journal of Latest Trends in Engineering and Technology, Vol. 2 Issue 1 January 2013.

[7] Deepak Punetha, Vartika Mehta, "A Wireless Approach to Real Time Remote Monitoring System consisting of Environmental Parameters using feasibility of a GSM module," IEEE International Conference on Advances in Engineering \& Technology Research (ICAETR'14), Unnao, Kanpur, Uttar Pradesh, 1-2 August 2014.

[8] Deepak Punetha, Vartika Mehta, "Protect the Child/ Elderly/ Disabled/ Pet by Smart and Intelligent GSM and GPS based Automatic Tracking and Alert System," IEEE International Conference on Advances in Computing, Communications and Informatics (ICACCI'14), Second International Symposium on Women in Computing and Informatics, Galgotias, Greater Noida, Uttar Pradesh, pp: 2349-2354, 24-27 September 2014.

[9] Deepak Punetha, Deepak Kumar and Vartika Mehta, "Design and Realization of the Accelerometer based Transportation System (ATS)," International Journal of Computer Applications 49(15):17-20, July 2012.
Published by Foundation of Computer Science, New York, USA.

[10] Deepak Punetha, Neeraj Kumar, Vartika Mehta, "Development and Applications of Line Following Robot Based Health Care Management System," International Journal of Advanced Research in Computer Engineering \& Technology, Vol. 2, no. 8, pp. 2446-2450, August-2013.

[11] M. Zafri Baharuddin, Izham Z. Abidin, S. Sulaiman Kaja Mohideen, Yap Keem Siah, Jeffrey Tan Too Chuan,"Analysis of Line Sensor Configuration for the Advanced Line Follower Robot", University Tenaga Nasional.

[12] Pakdaman, M.; Sanaatiyan, M.M., "Design and Implementation of Line Follower Robot," Computer and Electrical Engineering, 2009. ICCEE '09. Second International Conference on , vol.2, no., pp.585-590, 28-30 Dec. 2009.

[13] T. Gomi, K. Ide,"Evolution of gaits of a legged robot", IEEE International Conference on Fuzzy Systems 06/1998; DOI:10.1109/ FUZZY.1998.687476 ISBN: 0-7803-4863-X In proceeding of: Fuzzy Systems Proceedings, 1998

[14] Deepak Punetha, Divakar Mani Tripathi, Ashish Kumar, "A Wireless Approach with Sensor Network for Real Time Railway Track Surveillance System," International Journal of Engineering Trends and Technology (IJETT), Vol. 9, Number 9, 426-429 March 2014.

[15] Deepak Punetha, Pratyush Jha, Shweta Singh, "An Intelligent Transportation System with Computer System Architecture approaching Safe Passage in Adaptive Traffic Light," International Journal of Computer Networks and Wireless Communications, Vol. 4, Number 2, pp. 143- 149, April 2014.

[16] Datasheets of microcontroller AT89C51, LDR sensor, IR proximity sensor, Motor driver L293D, Comparator, 16*2 LCD, Available: http:// www.alldatasheet.com

[17] Miller Peter, "Building a Two Wheeled Balancing Robot", University of Southern Queensland, Faculty of Engineering and Surveying. Retrieved Nov 18, 2008.

[18] Nor Maniha Abdul Ghani, Faradila Naim, Tan Piow Yon, "Two Wheels Balancing Robot with Line Following Capability," World Academy of Science, Engineering and Technology, pp-634-638, 2011.

[19] Román Osorio," Inteligent Line Follower Mini-Robot System", International Journal of Computers, Communications \& Control Vol. I, No. 2 ,pp. 73-83,2006.

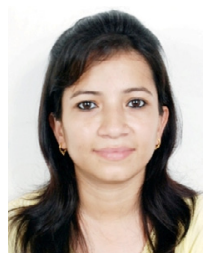

Ms. Vartika Mehta is serving SIT, Pithoragarh as an Assistant Professor in E.C.E. department. He has an experience of more than 4.5 years in teaching and Software companies. She has completed her B.Tech in ECE from Dehradun Institute of Technology and M.Tech in Communication System from Graphic Era Hill University, Dehradun, Uttarakhand, India. Signals and Systems. She has published so many research papers in various National and International conferences and journals. She is also the member of many research organizations. Her area of interest is Joomla, Opencart frame work, Executing test cases, Jmeter tools, Xampp server, Wireless Communication,

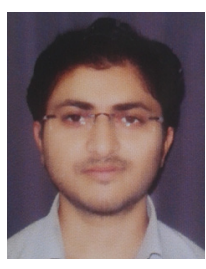

Mr. Deepak Punetha is serving Tula's Institute, Dehradun as an Assistant Professor in E.C.E. department. He has an experience of more than 5.5 years in teaching and research (Including research experience in CDAC, Mohali). He has completed his B.Tech in ECE from Dehradun Institute of Technology and M.E. (8.5 CGPA) in EPDT from PEC University of Technology, Chandigarh. His area of interest is Electronics Product Design and Technology, Face Recognition and Compression, Radiation Pattern analysis of different Antennas, Navigation and Emergency Alerting System, Robotics and Embedded Systems. He has published more than 35 research papers in reputed conferences and International Journals. He is the member of reviewing and technical program committee of IEEE Explorer, Springer (Journal of Intelligent \& Robotics Systems), Hindawi and various international Journals. He is also an active member of different National and International Association of Electronics and Communication Engineers and Editorial Boards. 


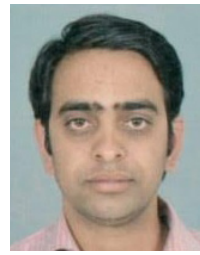

Mr. Vishwanath bijalwan obtained his B.Tech degree in ECE, from Dehradun Institute of Technology (UPTU) in 2009. He received his M.TECH degree from Uttarakhand Technical University in Digital Communication stream in 2012. Currently he is working as an Assistant Professor \& head of the department ECE at IT,Gopeshwar (State Government Institute). Besides this he has been also serving some more academic duties of Examination controller, \& Dean Student's welfare at IT Gopeshwar. He has more than 5 years of teaching experience and 1 year industry experience. He has worked for various organizations, such as HCL Info system, Doon Institute of Engg. \& Technology Rishikesh, Uttaranchal University Dehradun, and Institute of Technology, Gopeshwar. In Research domain he has published various research papers in international journals. His research area of interest is Wireless adhoc network, IEEE 802.15.4, \& Machine learning. He has served as a PC member for many national \& International conferences in the region; he is also serving as a reviewing board member for various international journals like OMICS group and various IEEE conferences. He is also an active member of IAENG, UACEE. His teaching area of Interest is Digital Electronics, Electromagnetic field theory, Antenna \& wave propagation \& digital signal processing. 